\title{
SINGLE CHANNEL SEISMIC APPLICATION FOR GAS CHARGED SEDIMENT RECONNAISSANCE IN GEOHAZARD STUDY OF PORT CONSTRUCTION AT WETLAND AREA
}

\author{
Taufan Wiguna*, Omar Moefti, Rahadian, Muhamad Irfan \\ Technology Center for Marine Survey, Agency for the Assessment and Application of \\ Technology, M.H. Thamrin St. No. 8, Jakarta Pusat, 10340
}

Received: 29 August 2016; Revised: 5 September 2016; Accepted: 4 October 2016

\begin{abstract}
Gas-charged sediment is one of the parameter for geohazard study in infrastructure, especially in a swamp area. Instability of sediment layer for example subsidence and landslide result in geohazard potential is caused by gas-charged sediment. The seismic single channel can be used to identify gas charged sediment location. Seabed morphology is collected from bathymetry and tidal survey. From the seismic profile, interpretation shows gas-charged sediment indication in Line A and Line B. Those indications emerged by the presence of acoustic turbid zone and acoustic blanking. The location of Line A and Line B will be the spotlight in next geotechnical port construction study.
\end{abstract}

Keywords: Single channel seismic; Gas charged sediment; Geohazard

\section{Introduction}

Gas-charged sediment is the saturated free gas in groundwater produced by biogenic or thermogenic event. ${ }^{1-2}$ It is related to seabed stability and to be stable under certain conditions of pressure, temperature, gas composition and salinity of specific pore, with human disturbances (development of a construction) or disorder directly from nature (earthquakes). It can convert the richmethane gas sediment into the rich-fluid reservoir. This conversion is occurred for the fluid invasion into the empty cavity filled by methane gas. ${ }^{3}$ The concentration of the fluid can trigger subsidence, avalanches, or debris, especially if nearby an engineering construction site. Therefore Gas-charged sediment takes a certain physical parameter to be ever measured. ${ }^{4}$ Sediments that fill with fluid have the potential hazard of ground movement such as flow, fall, and slide). ${ }^{5}$ Loose gas-charged sediment (uncharged sediments) will cause land subsidence (subsidence) and form a pockmark.

An example of subsidence events that can be caused by gas-charged sediment is a street collapsed at R.E. Martadinata St. (North

* Corresponding author.

E-Mail: taufan.wiguna@bppt.go.id
Jakarta) in September 2010 (Figure 1). ${ }^{6}$ The depositional environment of that collapse is similar to the study area thus the subsidence can be an issued for the study area.

This study was located in the wetland area at Riko River, Penajam Paser Utara, East Kalimantan (Figure 2). In the eastern area is dominated by the settlement while in the western area of the mangroves. Therefore, gas-charged sediments may potentially induce geological hazards.

The aim of this study is to complete the subsurface data in the port construction area and to determine gas-charged sediment existence.

\section{Methods}

Single channel seismic acquisition applied boomer (Geoacoustic CSP300) as acoustic wave source (Figure 3) with an energy of 200 Joule/second. GPS and navigation software (Hypack) were applied to generate georeferenced data (Figure 4). The sampling rate was done every two seconds. The seismic profile was showed vertically by SonarWiz software in SEG-Y format. 


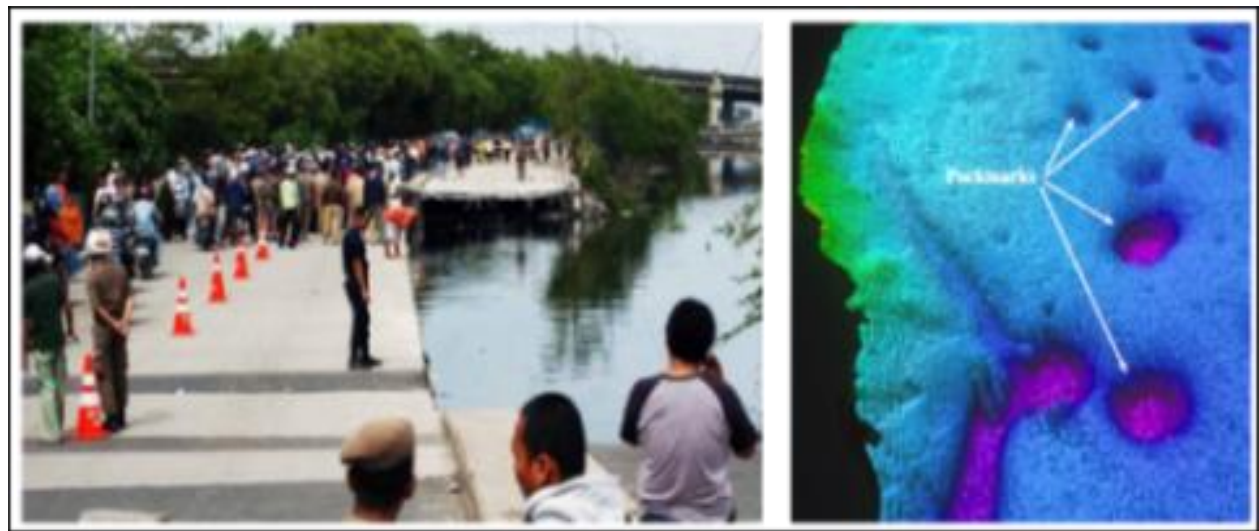

Figure 1. Left: Subsidence at Jl. R.E. Martadinata (North Jakarta), September 2010; ${ }^{6}$ Right: Pockmark caused by subsidence ${ }^{7}$

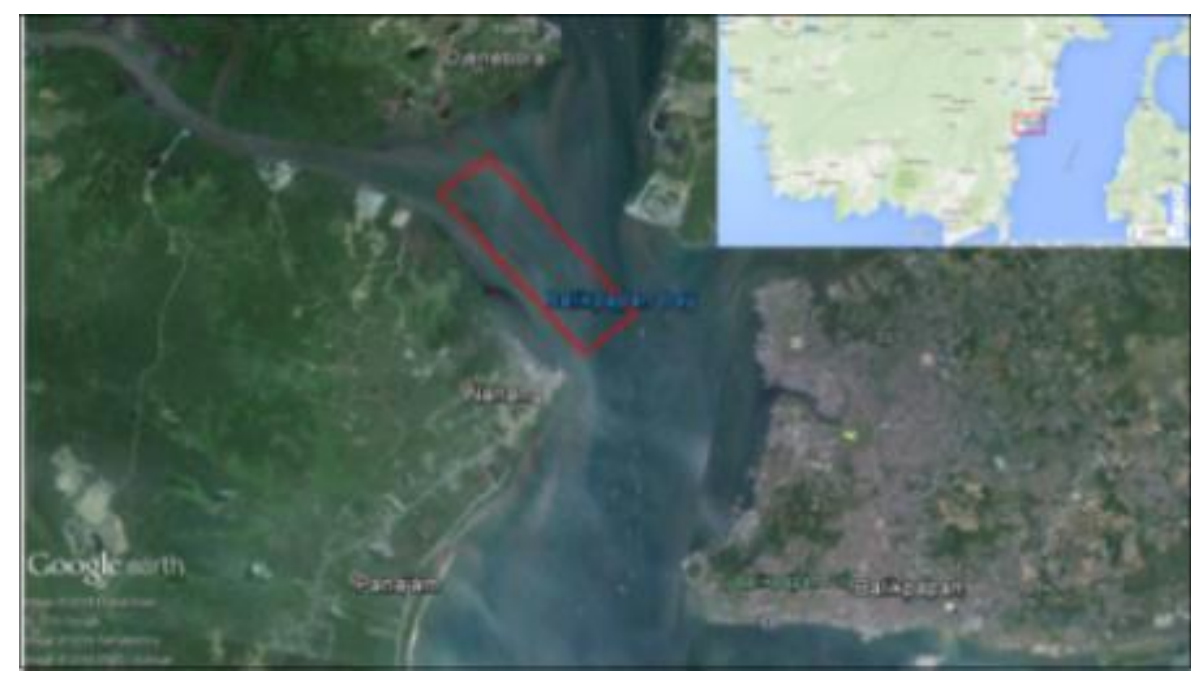

Figure 2.Research Location

Bathymetric map (Figure 5) as supporting data was used to determine the seabed morphology. Bathymetric map data processing was corrected by real-time tidal data using tide gauge (Figure 3).

Interpretation of gas-charged sediment existence was done in single channel seismic profile. The interpretation refers to Papatheodorouet. al. (Figure 6). ${ }^{8}$

\section{Result and Discussion}

The study area experiencing sediment deposition stages which are allow gas methane generation. There are three interest seismic profiles-Line 1, Line A, and Line B. Interpretation of these profiles are:

- Line 1 (Figure 7) shows channel deposit. It means the study area is organic material deposition area and potential to produce methane gas

- Line A (Figure 8) shows gas-charged sediment appearance marked by acoustic turbid zone and gas plume.

- Line B (Figure 9) shows gas-charged sediment marked by acoustic turbid zone and dome (which can be a potential gas plume)

- Gas charged sediment that was found in study area are:

- at depth 5.4 meter on seabed (Line A)

- at depth 6.3 meter and 5.4 meter below seabed (Line A)

- at 13.5 meter below seabed (Line B)

Bathymetric map (Figure 5) shows a high topographic at the northern area. This accord the seismic interpretation from Line 1 which is this area dominated by sedimentation. 


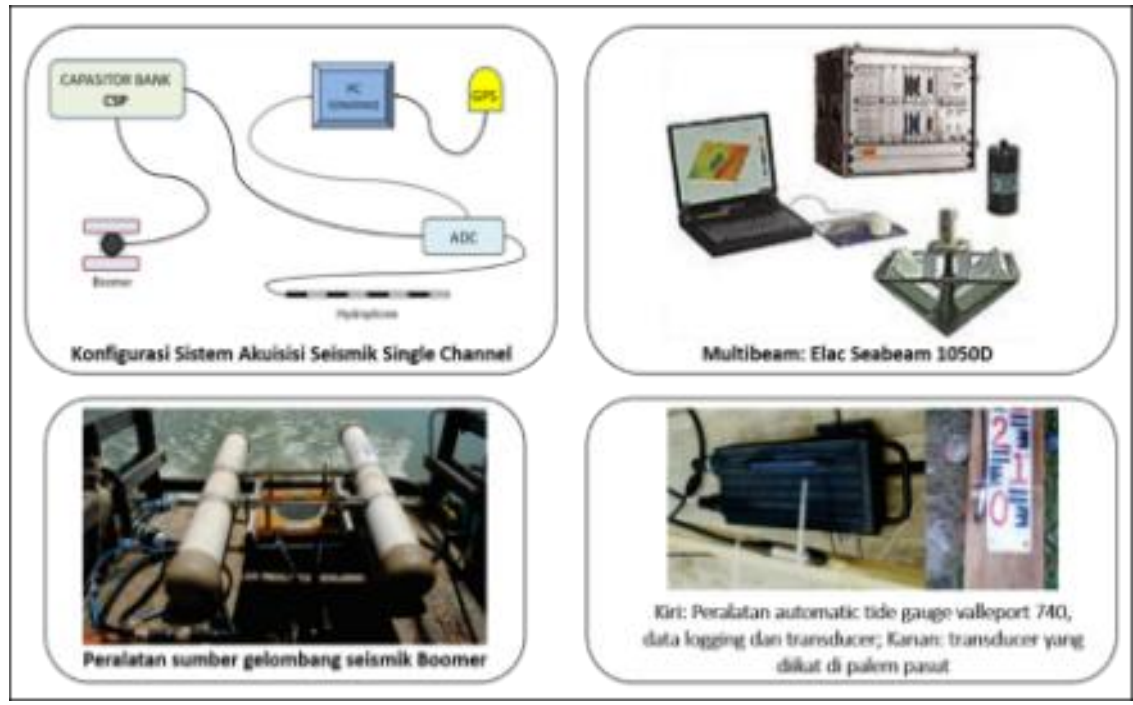

Figure 3. Equipments

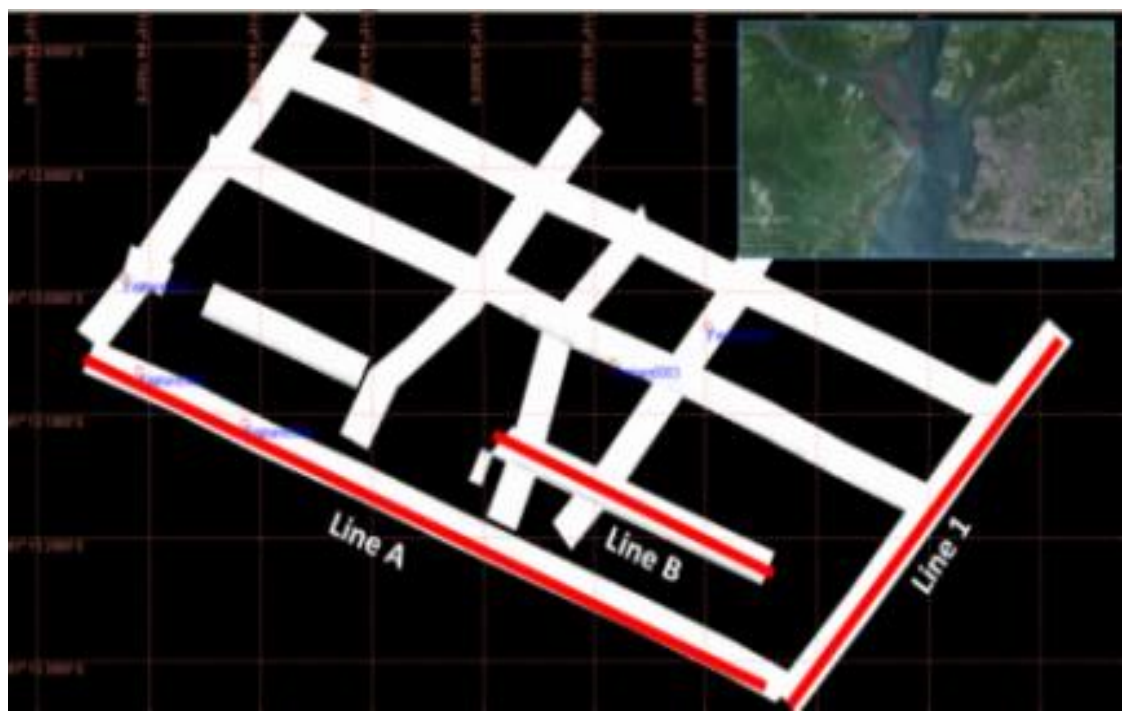

Figure 4. Single channel seismic line in study area

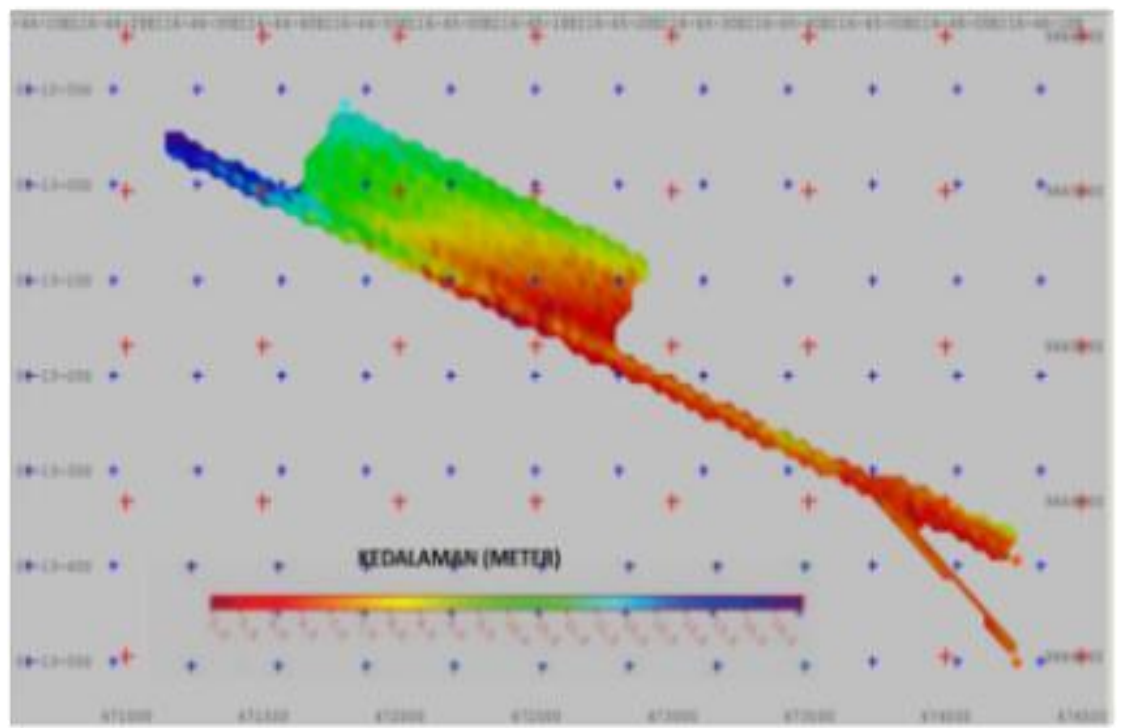

Figure 5. Bathymetric map in study area 


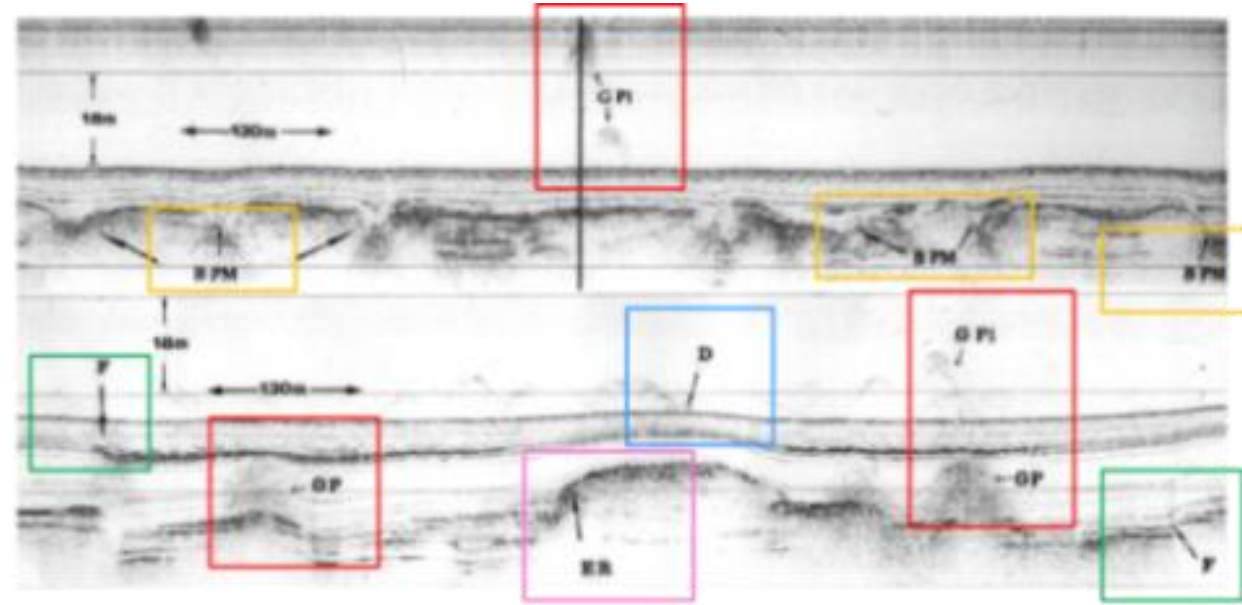

(1) Gas Plume, (2) Dome, (3) Fault, (4) Enhanced Reflectror, (5) Burial Pockmark

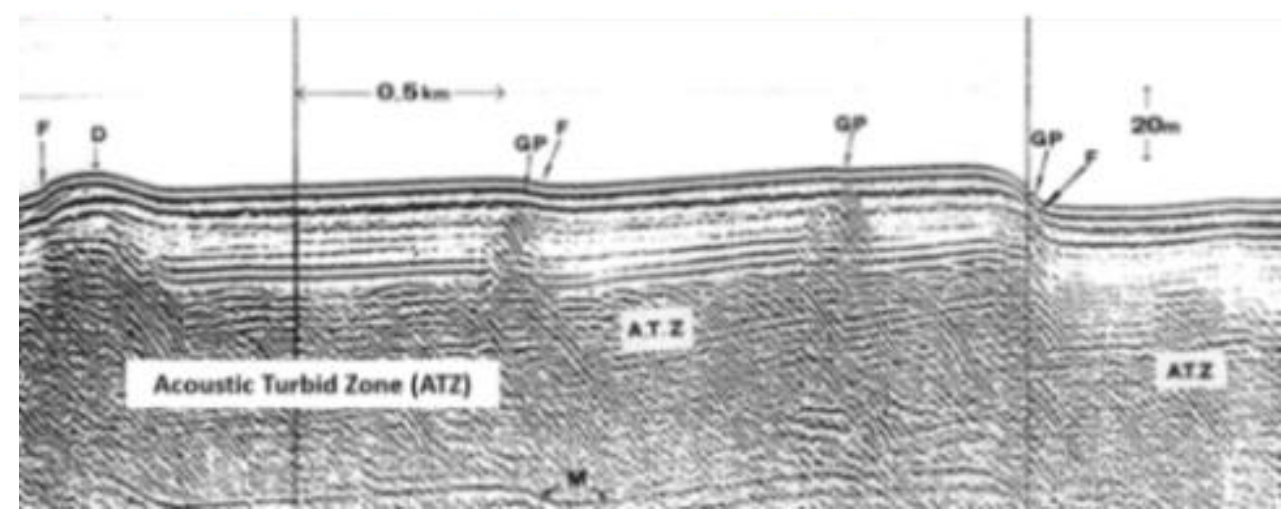

Figure 6. Gas Charged sediment benchmark [8]

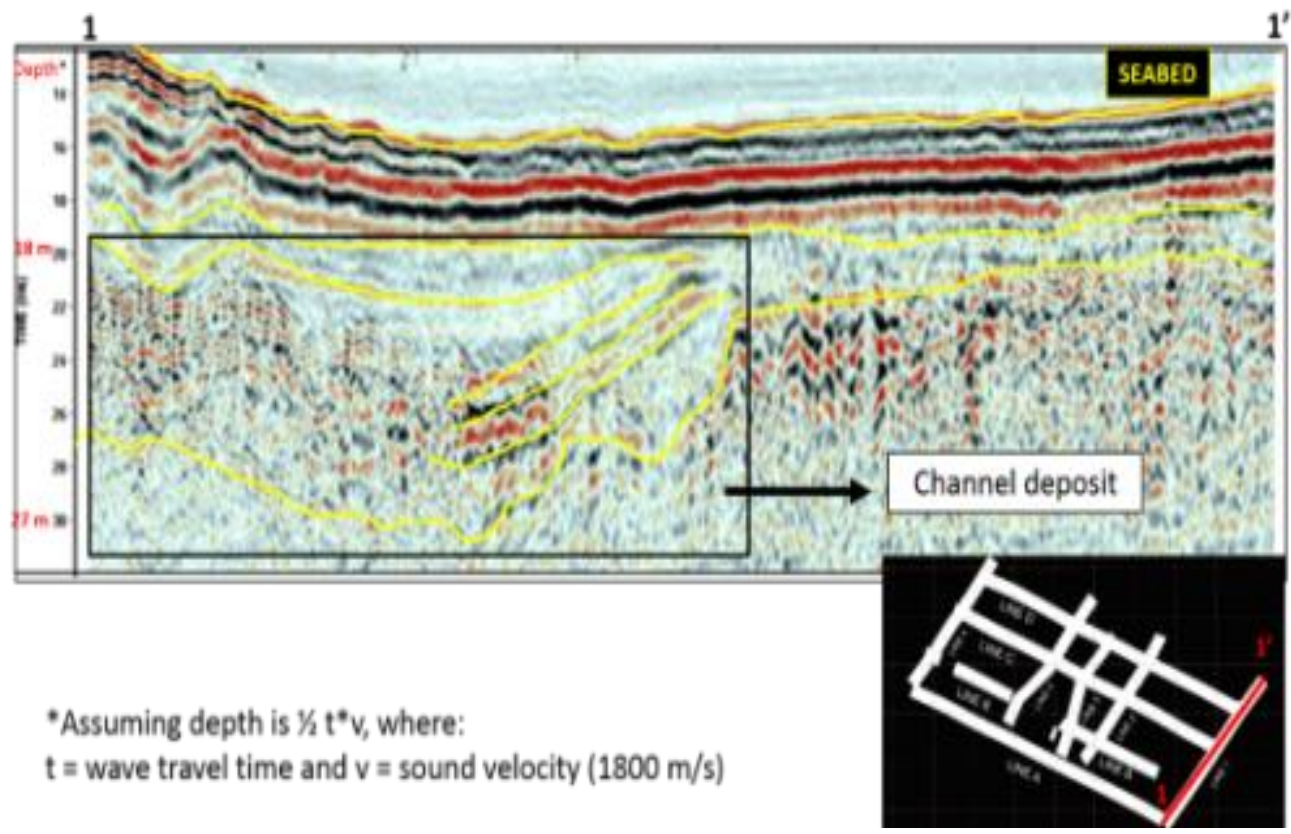

Figure 7. Line 1 Seismic Profile 


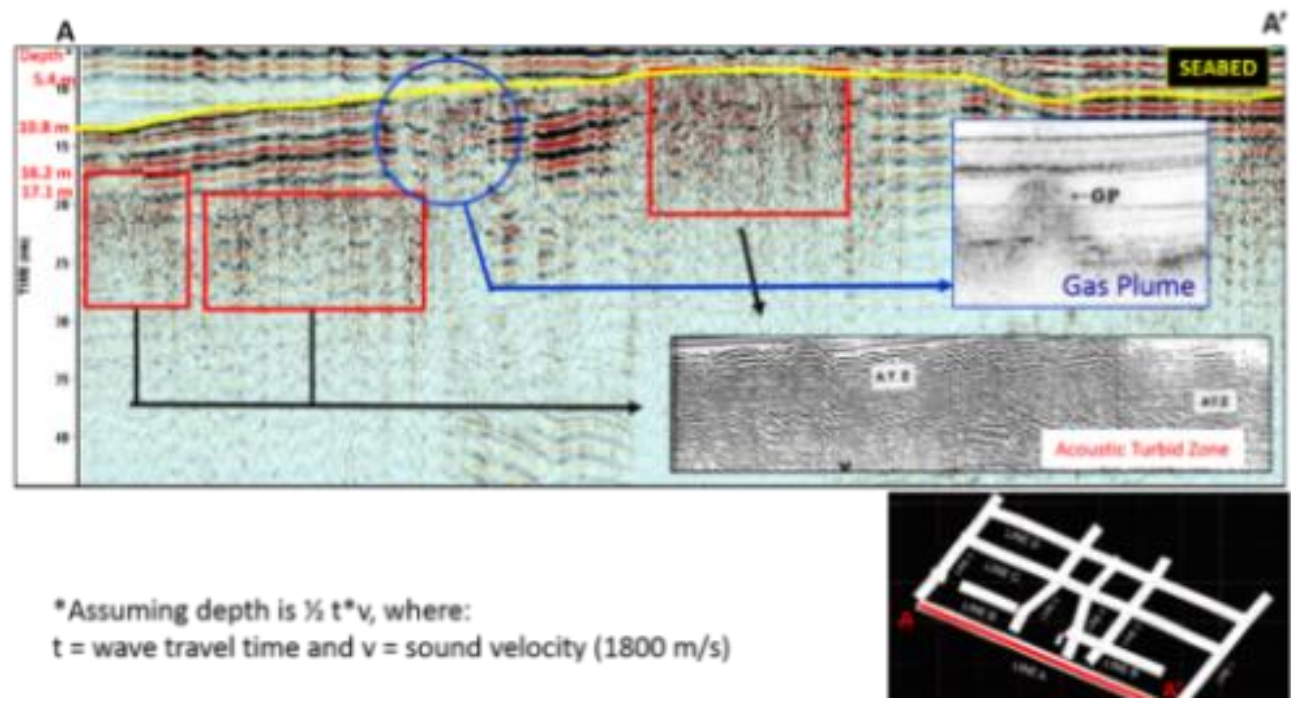

Figure 8. Line A Seismic Profile

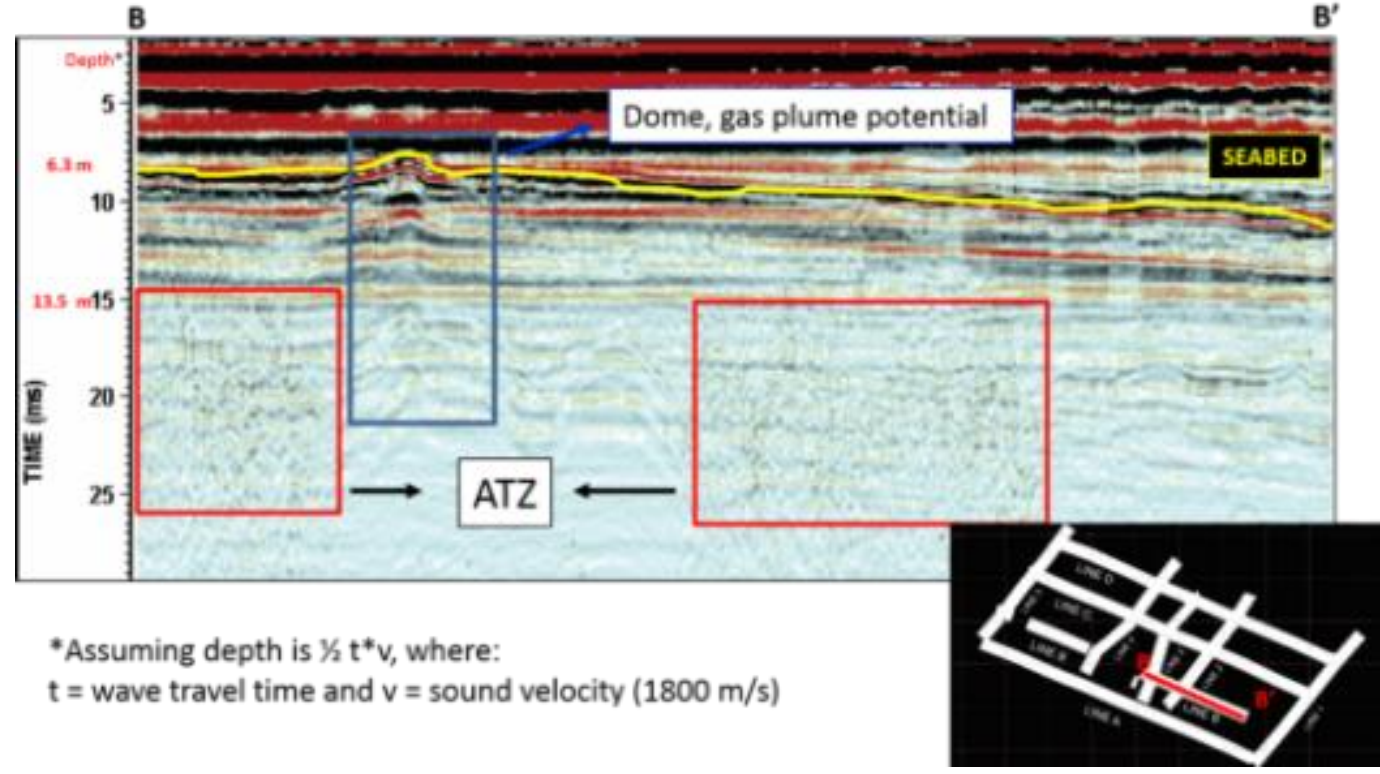

Figure 9. Line B Seismic Profile

\section{Conclusion}

Gas charged sediment reconnaissance at Kabupaten Penajam Paser Utara apply seismic single channel can be concluded as follows:

- Seismic Single Channel can be applied for gas charged sediment reconnaissance in geohazard study

- It needs more comprehensive investigation to reduce the impact of gas charged sediments
- Construction in wetland areas require a study of potential hazards including gas charged sediment

\section{Acknowledgment}

Thanks to Dr. M. Ilyas (Head of Technology Center for Marine Survey BPPT) for his supporting to this publication. This study was founded by Program Pusat Pengembangan Ilmu Pengetahuan dan Teknologi Kelautan (PUSPIPTEKLA) TA 
2012 which is led by Ir. Djunaedi Muljawan, M. Sc. Thanks to Dr. Agus Sudaryanto for his advice in writing this paper.

\section{References}

1. Fleischer P., Orsi T. H., Richardson M. D., \& Anderson A. L. Distribution of free gas in marine sediments: a global overview. Geo-Marine Letters. 2001; (21): 103-122.

2. Sills G. C. \&Thomas, S. D. Pore pressure in soil containing gas. In: Di Maio C., Hueckel T., Loret B. ChemoMechanical Coupling in Clays; From nano-scale to engineering applications. CRC Press; 2002: 211-222.

3. Sunjay and Jain N. Geophysical Study of Gas Hydrate Stability. Conference: Environmental Management and Current Practices in Mining and Allied Industries, At Varanasi, Volume: 1. 2014. DOI: 10.13140/RG.2.1.1627.1208

4. Jang, Junbong. Gas-Charged Sediments: Phenomena and Characterization
[Thesis]. USA: Georgia Institute of Technology. 2014

5. Hansen, M.J. Strategies for Classification of Landslides. In: Brunsden, D, \& Prior, D.B. Slope Instability. John Wiley \& Sons. 1984:125

6. Amri A. B. and Mahaputra S. A. Jalan RE Martadinata Ambles Lagi [Internet].VivaNews. September $18^{\text {th }} 2010 \quad$ [cited May $\left.1^{\text {st }} 2016\right]$. http://metro.news.viva.co.id/news/read/1 78163-jalan-re-martadinata-amblas-lagi. Internet

7. Natural Resources Canada. Shaping the Harbour through Modern Geological Processes.[modified October $12^{\text {th }} 2007$; cited May $1^{\text {st }}$ 2016]. http://www.bedfordbasin.ca/halifaxharbo ur/geological_processeseng.php\#methane. Internet

8. Papatheodorou, G., Hasiotis, T., and Ferentinos, G. Gas-charged sediments in the Aegean and Ionian Seas, Greece. 1993. Marine Geology (112): 171-184. 